\title{
Marine Oil-Degrading Microorganisms and Biodegradation Process of Petroleum Hydrocarbon in Marine Environments: A Review
}

\author{
Jianliang $\mathrm{Xue}^{1} \cdot{\text { Yang } \mathrm{Yu}^{2} \cdot \mathrm{Yu} \mathrm{Bai}^{3} \cdot \text { Liping Wang }}^{4} \cdot$ Yanan $\mathrm{Wu}^{1}$
}

Received: 12 January 2015 / Accepted: 12 March 2015/Published online: 28 April 2015

(C) Springer Science+Business Media New York 2015

\begin{abstract}
Due to the toxicity of petroleum compounds, the increasing accidents of marine oil spills/leakages have had a significant impact on our environment. Recently, different remedial techniques for the treatment of marine petroleum pollution have been proposed, such as bioremediation, controlled burning, skimming, and solidifying. (Hedlund and Staley in Int J Syst Evol Microbiol 51:61-66, 2001). This review introduces an important remedial method for marine oil pollution treatment-bioremediation technique-which is considered as a reliable, efficient, cost-effective, and eco-friendly method. First, the necessity of bioremediation for marine oil pollution was discussed. Second, this paper discussed the species of oil-degrading microorganisms, degradation pathways and mechanisms, the degradation rate and reaction model, and the factors affecting the degradation. Last, several suggestions for the further research in the field of marine oil spill bioremediation were proposed.
\end{abstract}

Liping Wang

liping.wang@mymail.unisa.edu.au

1 College of Chemical and Environmental Engineering, Shandong University of Science and Technology, Qingdao 266590, Shandong, China

2 Laboratory Technician, Citic Pacific Mining Management Pty Ltd, Karratha, WA 6714, Australia

3 Key Laboratory of Environmental Aquatic Chemistry, Research Center for Eco-Environmental Sciences, Chinese Academy of Sciences, Beijing 100085, China

4 Sansom Institute for Health Research, School of Pharmacy and Medical Sciences, University of South Australia, Adelaide, SA 5001, Australia

\section{Introduction}

Petroleum is one of the most important raw materials for the production of petroleum fuels (e.g., gasoline and kerosene) and chemical reagents products (e.g., pharmaceuticals, solvents, fertilizers, and plastics) [32]. Due to the increasing global petroleum demand, more and more activities such as exploitation, extraction, refining, and transportation of petroleum have been conducted. At the same time, about half of these petroleum products are transported across the world by sea [56]. Consequently, there is a dramatic increase of the petroleum spill or leakage accidents all over the world, such as spills from oil wells, pipelines, drilling rigs, or transport tankers.

More importantly, these oil spill accidents could cause severe physical, chemical, and biological hazards towards the local marine environment. For example, these accidents (e.g., "Exxon Valdex", "DeepWater Horizon" oil spill accident in the Gulf of Mexico and "Penglai 19-3" oil spill accident in 2011) have brought serious environmental damage to the local region. For example, comparison with these oil spill accidents in the 21 st century, "DeepWater Horizon" oil spill accident in the Gulf of Mexico was the most serious oil accident. The accident did not only lead to the great financial loss, e.g., in the fishing industry, but also damaged wetlands and beaches seriously.

First, oil spill accidents could affect marine meteorological environment via dispersion, dissolution, emulsification, and evaporation of the crude oil [37]. Once oil is spilled into the sea, it could spread over the surface of the seawater. Some research reported that a ton of spilled oil can form $5 \times 10^{6} \mathrm{~m}^{2}$ of slick on the surface of the sea water. The slick could block the $\mathrm{O}_{2} / \mathrm{CO}_{2}$ exchange directly and lead to an oxygen depletion and $\mathrm{pH}$ change in the sea water. Besides, slick could also influence water evaporation and 
precipitation in marine environment. Thus, some reports indicated that marine desertification was caused by oil spill accidents [51].

In addition, oil spill accidents have a serious impact on the marine/terrestrial ecosystems and human health. For example, oil slick forms an anaerobic condition in the sea water and leads to the death of flora and fauna. Oil spills can cause hypothermia of marine birds and mammals by reducing/destroying the insulating ability of the plumage of birds and the fur of mammals. Meanwhile, the toxic constitutes in petroleum could poison or kill birds, mammals, fishes and other marine organisms and damage the fragile underwater ecosystems which lead to a vicious effect on the global food chain, and eventually harm human health by damaging internal organs, such as kidneys, lungs, and liver [21, 46]. Moreover, oil spill accidents could affect marine plants and agricultural production by blocking light and gaseous exchange. It is estimated that half of the total coastal wetland loss was caused by oil spill accidents [46]. At last, the oil pollution in marine environment can cause significant economic losses in tourism and marine resource industries, such as coastal salt industry, marine chemical production, marine aquaculture, and fishery industry.

At present, different cleanup and recovery methods for the oil spills have been developed including physical (e.g., controlled burning, skimming, and absorbing), chemical (e.g., dispersing and solidifying), and bioremediation treatments $[2,8,38,50]$. Generally, physical and chemical treatments should be taken as emergency measures. For example, at the start of the oil spill accident, the physical and chemical treatments are taken, in order to rapidly control the diffusion and drift of oil. These methods are not suitable for ecological restoration.

Bioremediation is considered as one of the most important eco-friendly and cost-effective technologies for marine ecological restoration, which leads to a complete decomposition of complex petroleum hydrocarbons of spilled oil into nontoxic compound. In the bioremediation process, appropriate microorganism is essential for the biotransformation/ biodegradation of the pollutant. In these accidents, the bioremediation have been used in the Exxon Valdez oil spill. In this article, different species of petroleum degradation microorganism and degradation pathways of biodegradation were discussed. The article could lay a good foundation for the further development of bioremediation technology.

\section{Advantages and Necessity of Bioremediation}

Compared with conventional physical and chemical methods, bioremediation technology is less expensive and highly effective for the marine ecological restoration, which has the following advantages [20, 32, 40, 80].
Bioremediation is One of the Most Environmentally Friendly Technologies

The essence of bioremediation technology is that petroleum is degraded into simple harmless inorganic products (e.g., $\mathrm{CO}_{2}$ and $\mathrm{H}_{2} \mathrm{O}$ ) during the microbial metabolism process, which could re-enter the biogeochemical cycle easily [80]. However, due to the complex chemical structure, the petroleum compounds are degraded into other chemicals compounds instead of $\mathrm{CO}_{2}$ and $\mathrm{H}_{2} \mathrm{O}$ by conventional physical and chemical methods. At the same time, secondary pollutants could be produced, which have the potential of damaging the marine environment.

\section{Bioremediation is One of the Most Cost-Effective Technologies}

Compared with physical and chemical treatments, bioremediation is based on its physical, chemical, and biological processes in the seawater-microorganisms-pollutants system, and the oil pollutant is removed by the metabolism process of microorganisms. According to the survey, compared to the costs of chemicals and physical methods, bioremediation method can save $\sim 50-70 \%$ of the costs [45].

\section{Bioremediation is a Highly Efficient In Situ Technology}

Some studies indicated that it is practicable to transfer the specific or genetically engineered oil-degrading microorganisms to the oil contaminated site for in situ bioremediation under favorable environmental conditions.

\section{Species and Distribution of Petroleum Degradation Microorganisms in Marine Environment}

Since the middle of the last century, the use of petroleum degradation microorganisms for spilled oil bioremediation has been widely reported $[47,68,70]$.These studies have indicated that different species of petroleum degradation microorganisms are broadly distributed in marine environment. Once other dominant groups of microorganisms are inhibited after oil contamination while these petroleum degradation microorganisms propagate rapidly and become dominant species [9].

In marine environment, more than 100 genera, 200 species of petroleum degradation microorganism (e.g., bacteria, fungi, algae, etc.) have been found, including bacteria (79 genera), cyanobacteria ( 9 genera), fungi (103 genera), and algae (19 genera) [10, 11, 17, 24, 34, 39, 59]. 
For example, in marine environment, bacterium plays an important role in petroleum degradation microorganism, e.g., Achromobacter, Acinetobacter, Alcaligenes, Archrobacter, Bacillus, Flavobacterium, Coryneforms, Microbacterium, Micrococcus, Pseudomonas, Actinomycetes, Nocardia, Aureobasidium, Candida, Rhodotorula, and Sporobolomyces. In addition, some species of Fungus including Aspergillus, Mucor, Fusarium, and Penicilium are also petroleum degradation microorganism. Gordonia is widely distributed in land, coastal, and ocean environments, and could degrade various environmental pollutants, including benzothiophene, dibenzothiophene, alkanes, polycyclic aromatic hydrocarbons, and so on [54, 67]. Different types of oil-degrading microorganisms are shown in Table 1.

\section{Degradation of Petroleum by Degrading Microorganisms}

\section{Degradation Pathways and Mechanism}

Generally, petroleum compounds are biodegraded, followed by three processes. At first, petroleum compounds are absorbed onto microbial surface; Second, these petroleum compounds are transferred to microbial cell membrane; then, these compounds are degraded in the microbial cell. At last, these compounds are degraded into various small molecules by microorganisms [6].

At present, many researches have showed that the degradation way of all sorts of petroleum components (e.g., alkane, polycyclic aromatic hydrocarbons, etc.) is an oxidizing process $[6,13,61,78]$. However, the degradation pathways of these compounds are different, due to the different structures of petroleum components, such as saturated, aromatic, resin, and asphaltene fractions hydrocarbon.
Degrading Process of Alkane and Cycloalkane

Alkane (general formula: $\mathrm{C}_{n} \mathrm{H}_{2 n+2}$ ) is a typical saturated hydrocarbon with all single bonds in the structure. Cycloalkane (general formula: $\mathrm{C}_{n} \mathrm{H}_{2 n}$ ) is another saturated hydrocarbons with several carbon rings in the structure.

The degrading process of alkane by microorganisms is shown in Fig. 1, which can be classified into three forms: subterminal oxidation, alkyl hydroperoxides, and degradation of cyclohexane [32]. Basically, alkane is catalyzed by some enzymes (e.g., oxidase, dehydroge, etc.) of microorganisms into fatty acids, and then gradually metabolized to acetyl coA and krebs cycle of microbial metabolism, eventually into $\mathrm{CO}_{2}$ and $\mathrm{H}_{2} \mathrm{O}$ [66]. In this process, enzymes (e.g., alkane monooxygenase, fatty alcohol dehydrogenase, fatty aldehyde dehydrogenase, etc.) play an important role in catalyzing the degradation process effectively.

Much like alkane, the biological degradation principle of cycloalkane is also subterminal oxidation. At first, cycloalkane is oxidized to alcohols by kinds of oxidizing enzyme. Then, the alcohols are converted to ketone by dehydroge. Later, the ketone is oxidized to esterase or/and fatty acid. Taking the cyclohexane for example as shown in Fig. 1, cyclohexane is converted to corresponding compound, followed by cyclohexanol, cyclohexanone, dehydroge, and fatty acid. At last, the compound is biodegraded into $\mathrm{CO}_{2}$ and $\mathrm{H}_{2} \mathrm{O}$.

In addition, cycloalkane with various substituents could be oxidized. The alkyl substituted alicyclic compounds may be two position is in the side chain oxidation and alicyclic compounds, the properties, microbial species, and other factors will influence the initial position of the reaction.

Table 1 The typical offshore oil-degrading microorganisms

\begin{tabular}{ll}
\hline & Microorganism colonies \\
\hline Bacterium & Achromobacter, Acinetobacter, Alcaligenes, Actinomycetes, Archrobacter, Bacillus, Cycloclasticus, Coryneforms, \\
& Chromobacterium, Flavobacterium, Micrococcus, Microbacterium, Mycobacterium, Nocardia, Pseudomonas, \\
& Sarcina, Serratia, Streptomyces, Vibrio, Xanthomonas. \\
Fungus & Mold: Penicillium, Aspergillus, Fusarium, Geotrichum, Gliocladium, Mucor, \\
& Yeast: Acremonium, Aspergillus, Aureobasidium, Pichia Candida maltosa, Candida tropicalis, Candida apicola, \\
& Candida, Cladosporium, Debaryomyces, Monilia, Mortierella, Rhodotorula, Saccharomyces, Toruplopsis, \\
& Trichoderma, Verticillium. \\
& Other fungus: Aureobasidium, Candida, Rhodotorula \\
& Agmenellum, Amphora, Anabaena, Aphanocapsa, Chlorella, Chlamydomonas, Coccochlorise, Cylindrotheea, \\
Dunaliella, Microcoleus, Nostoc, Oscillatoria, Petalonema, Porphyridium.
\end{tabular}


Fig. 1 Degradation pathway of alkanes and cycloalkane

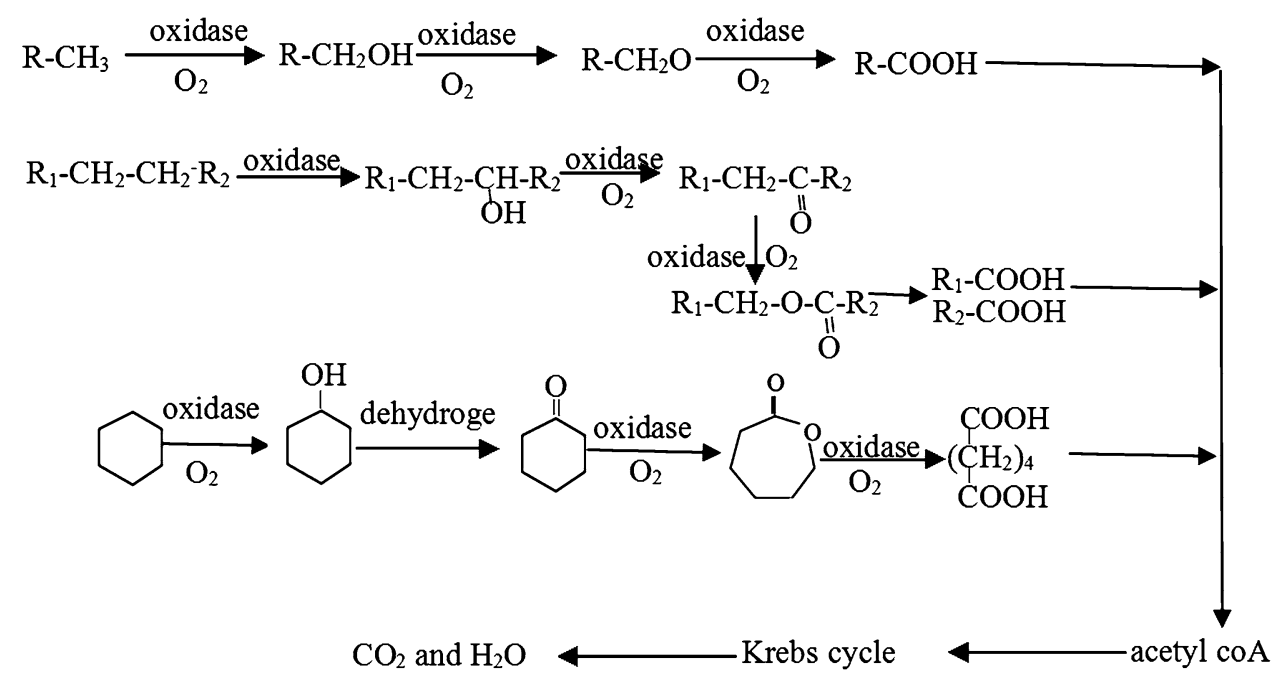

\section{Degrading Process of Aromatic Hydrocarbon}

The degrading process of aromatic hydrocarbon is as follows: at first, aromatic hydrocarbon is oxidized by oxidase to dihydrodiol. Then, dihydrodiol is degraded to o-dihydroxybenzene. O-dihydroxybenzene is degraded following two processes which are ortho-position ring opening reaction and meta-position ring opening reaction, respectively. Then, these compounds are oxidized to long chain compounds and are gradually metabolized to acetyl coA. The degrading process is shown in Fig. 2.

Some of fungus and bacterium could degrade aromatic hydrocarbon, the process is different from each other. Taking the bacterium for example, aromatic hydrocarbon is oxidized by two oxygen atoms, and converted to cis-dihydrodiol. But, aromatic hydrocarbon is oxidized and converted to trans-dihydrodiol by fungus.

\section{Degrading Process of Polycyclic Aromatic Hydrocarbons (PAHs)}

Polycyclic aromatic hydrocarbons (PAHs) are typically high carcinogenic, mutagenic, and teratogenic substance, which have drawn much attention to its degradation mechanism. It can be degraded under enzymes catalyzing into glycol or catechol groups, then further decomposed into acetyl coA or succinic acid [78]. Generally, the degradation pathway is that PAHs are gradually degraded into epoxide, trans diol, phenol, and trans dihydro 2 phenol by monooxygenase of yeast. Another pathway is that PAHs are gradually degraded by dioxygenase into epoxide, cis diol, cis dihydro 2 phenol, etc. The final metabolites in both pathways are carbon dioxide and water, and the overall steps of biodegradation of PAHs are demonstrated in Fig. 3 [49].

PAHs is different to be degraded, and the degraded level of PAHs should be graded in order of solubility, the number of benzene rings, the species and number of substituent species, the properties of heterocyclic atom, etc.

In addition, the asphalt has the most complicated structure, which is very difficult to be decomposed by biodegradation [62].

However, many researches indicated the PAHs could be degraded in aerobic conditions. While, other researches showed that PAHs also could be degraded in denitrification, sulfate reducing, or methanogenic fermentation under

Fig. 2 Degradation pathway of aromatic hydrocarbon

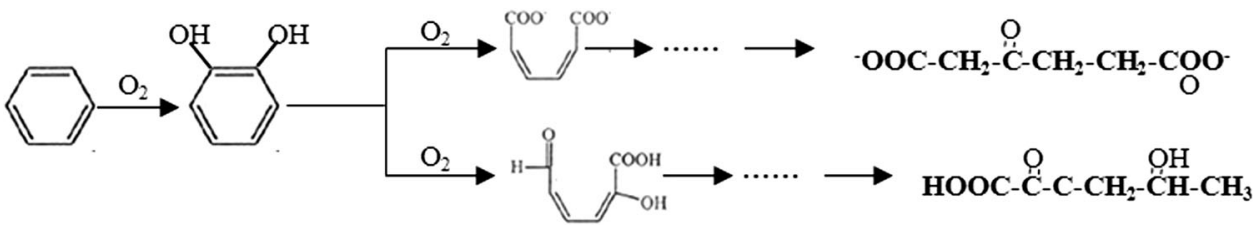

Fig. 3 Degradation pathways of polycyclic aromatic hydrocarbons (PAHs)

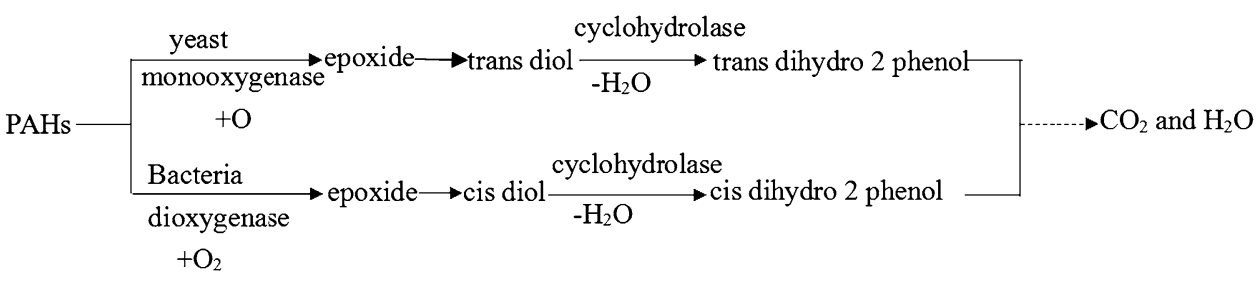


Table 2 Oil-degrading microorganisms and corresponding degrading substances

\begin{tabular}{|c|c|c|}
\hline Metabolic substances & Species & Reference \\
\hline Aliphatic hydrocarbon, cyclohexane, alkyl benzene, and dicycloalkane & $\begin{array}{l}\text { Pseudomonas; Corynebacterium; Bacillus; } \\
\text { Corynebacterium }\end{array}$ & [77] \\
\hline $\begin{array}{l}\text { Long carbon chain hydrocarbon component of oil and benzo (a) pyrene and } \\
\text { other substances }\end{array}$ & Aspergillius sp. Penicillium sp. & [69] \\
\hline $\begin{array}{l}\text { Naphthalene, 1-methylnaphthalene, 2-methylnaphtha-lene, 2,6- } \\
\text { dimethylnaphthalene, and phenanthrene }\end{array}$ & Vibrio cyclotrophicus sp.nov. & {$[35]$} \\
\hline Naphthalene, anthracene, phenanthrene, and pyrene & Aeram onas punctata TII & {$[14,53]$} \\
\hline Phenanthrene and Chrysene & Vibrio, Pseudoalteromonas, Marinomonas & [31] \\
\hline n-Alkanes aromatic hydrocarbon, naphthalene, phenanthrene and anthracene & Cycloclasticus oligotrophus & {$[23,73]$} \\
\hline$n$-Alkanes, branched alkanes and alkylbenzenes & Alcanivorax sp. & $\begin{array}{l}{[22,29,30} \\
\quad 48,75]\end{array}$ \\
\hline Aliphatic hydrocarbons, alkanoles, and alkanoates & Oleiphilusand, Oleispira & {$[28,74]$} \\
\hline Alkanes & Desulfococcus & [1] \\
\hline PAHs & Cycloclasticus & $\begin{array}{l}{[36,42,43,} \\
73]\end{array}$ \\
\hline Pyrene & Mycobacterium & {$[25,41,72]$} \\
\hline
\end{tabular}

anaerobic condition. Compared with the higher rate of aerobic degradation, the anaerobic degradation rate of PAHs is relatively slower. And, the anaerobic degradation pathway of the PAHs is also not clear at present [60].

\section{Specificity of Biodegradation}

Marine oil-degrading bacteria strains (e.g., Alcanivorax, Cycloclasticus, Marinobacter, Neptunomonas, Oleiphilus, etc.) could degrade alkanes or aromatic hydrocarbons [31]. Alcanivorax strains have a preference for $n$-alkanes and branched alkanes while Cycloclasticus can grow on the aromatic hydrocarbons [31]. Bacteria strains (Pseudomonas, Corynebacterium, Bacillus, and Corynebacterium) which were separated from the residual oil of Liaohe oil-field could degrade petroleum compounds in some extent: aromatic hydrocarbon $80 \%$; bitumen $53 \%$; aliphatic hydrocarbon $37 \%$; and nonhydrocarbon $30 \%$ [77]. Several typical oil-degrading microorganism and corresponding substances after degradation are listed in Table 2. Taking PAHs for example, Tropicibacter naphthalenivorans gen. nov. sp. could degrade naphthalene, phenanthrene, C1-alkyl naphthalene, and C2-alkyl naphthalene, except for two alkyl benzothiophene, alkyl phenanthrene and alkyl fluorine.

\section{Degradation Efficiency Rate}

Theoretically, all the petroleum components can be degraded into inorganic compounds by oil-degrading microorganisms according to the mechanism of degradation
[20]. However, many studies have shown that the degradation efficiency rate of petroleum is different due to the complexity of various petroleum hydrocarbons (e.g., molecular weight and structure, etc.) and the effect of the external environmental parameters (e.g., temperature, oxygen, salinity, pressure, nutrients, etc.).

\section{Molecular Weight of Petroleum Hydrocarbons}

Generally, the degradation efficiency rate of petroleum hydrocarbons decreases with the increase of the carbon number in petroleum compounds. Some researchers have indicated that short chain $n$-alkanes are the most easily degradable components followed by branched alkanes, aromatic hydrocarbon, cyclic aromatic hydrocarbon, asphaltenes, and lastly heavy crude oil [3]. Peng et al. found that the degradation of alkane was more effective than that of aromatics compounds [55]. By contrast, other researchers separated petroleum degrading microorganism from the strains in marine sediments that could breakdown aromatics hydrocarbons effectively [71].

\section{The Degradation Rate of Branched Hydrocarbons is Significantly Lower than that of $\boldsymbol{n}$-Alkanes Hydrocarbons}

The higher the content of branched hydrocarbons, the lower the degradation in the biodegrading branched hydrocarbons process. Thus, the degradation rate of branched hydrocarbons is lower [33]. Shi et al. have found that $91.1 \%$ of $n$ alkane was degraded in 7 days, while the degradation rate of 
Table 3 Degradation efficiency of co-metabolism

\begin{tabular}{lll}
\hline Metabolic substances & Species & Degradation efficiency \\
\hline $\begin{array}{l}\text { Naphthalene 2-methyl naphthalene } \\
\text { phenanthrene phenylbenzene }\end{array}$ & Vibrio cyclotrophicus sp. nov. & $\begin{array}{c}\text { Naphthalene can be degraded. While mix substance of } \\
\text { naphthalene, 2-methyl naphthalene, and phenanthrene are } \\
\text { degraded in higher degradation efficiency } \\
\text { Fluorine acenaphthene }\end{array}$ \\
$\begin{array}{l}\text { Fluorene, phenanthrene, } \\
\text { anthracene }\end{array}$ & $\begin{array}{c}\text { Peghylbenzene,fluorine, sand acenaphthene could be } \\
\text { Mix substance of fluorene, phenanthrene, anthracene could be } \\
\text { degraded, and the fluorene is degraded qucilkly. While, the other } \\
\text { substance is added, the degradation efficiency is improved }\end{array}$ \\
\hline
\end{tabular}

one basking alkanes and phytane in 21 days was 47.29 and $41.21 \%$, respectively [64]. Yuan et al. also found the degradation rate of branched hydrocarbons was nearly two times than that of $n$-alkanes hydrocarbons [77].

\section{Some Petroleum Components Could Affect the Degradation Efficiency Rate}

The content of sulfur composition in crude oil could affects the degradation rate. Generally, the low-sulfur petroleum hydrocarbons could be easily degraded by some microorganism [33, 66, 71]. However, saturated hydrocarbon with higher proportion of sulfur still has a higher degradation rate than aromatic compounds [66].

\section{Co-metabolism}

Generally, due to the complicated structure of petroleum compounds, the degradation efficiency rate is lower [63]. But, the degradation efficiency rate could be improved with other co-metabolism compounds. In this process, the simple compounds are favor to improve the ability of degradation. Taking PAHs for example, a variety of microorganisms (e.g., Bacteria, fungi, and prokaryotic algae) are able to degrade the PAHs through co-metabolism. For example, the degradation efficiency of pyrene could be improved and be up to $98.2 \%$ by adding $1 \%$ Osmocote and $0.1 \%$ Chitosan. Table 3 shows the degradation efficiency of PAHs was improved with co-metabolism. Some report also indicated that the degradation efficiency rate was shortened two months by co-metabolism compounds adding co-metabolism compounds. [58].

\section{Degradation Rate and Model}

In marine environment, type of petroleum hydrocarbons [19], temperature [4], species of microorganisms [31], and nutrients $[15,16]$ can affect the degradation rate of petroleum hydrocarbon. Different microorganisms have different tendencies to attack various types of petroleum hydrocarbons. Generally, the susceptibilities of hydrocarbons that can be degraded by microorganisms are as follows: $n$-alkane >branched alkane >small aromatics hydrocarbon $>$ polycyclic aromatic hydrocarbon (PAHs) [7, 20]. Temperature is another important parameter that determines the biodegradation rate of hydrocarbons by affecting the metabolic activity and the diversity of the microorganisms [57]. The biodegradation rate increases with increasing temperature and maximum rate occurs in the range of $15-20^{\circ} \mathrm{C}$ in marine environment $[5,20]$. Nutrients (such as nitrogen and phosphorus) can be the limiting factor that enhances the biodegradation rate of hydrocarbons [5, 44]. However, excessive nutrient concentration can also decrease the biodegradation rate of oil pollutant $[18,52]$.

\section{Degradation Rate}

Some researchers have considered that degradation rate could be inferred by establishing degradation model. And, some models were established to describe the biodegradation process [27, 76, 79, 81], such as the MichaelisMenten equation, shown in Eq. 1:

$v_{\mathrm{c}}=\frac{v_{\mathrm{c}, \max } \rho_{\mathrm{s}}}{K_{\mathrm{c}}+\rho_{\mathrm{s}}}$,

where $v_{\mathrm{c}}$ is the degradation rate $(\mathrm{g} / \mathrm{dL}) ; \rho_{\mathrm{s}}$ is the mass concentration of oil $(\mathrm{g} / \mathrm{L}), v_{\mathrm{c}, \max }$ is the maximum degradation rate $(\mathrm{g} / \mathrm{dL})$, and $K_{\mathrm{c}}$ is the $K_{\mathrm{s}}$ saturation constant, g/d.

Zhang et al. have found that [79] speed coefficient of degradation of dynamic plastic bacteria, $v_{\mathrm{c}, \max }$ and $K_{\mathrm{c}}$, was 0.27 and 1.04 respectively, under the condition of rich nutrition, but, under the condition of poor nutrition, $v_{\mathrm{c}, \max }$ and $K_{\mathrm{c}}$, was only 0.0034 and 0.41 , respectively. Similarly, under the condition of rich nutrition, speed coefficient of degradation of Pseudomonas genus, $v_{\mathrm{c}, \max }$ and $K_{\mathrm{c}}$, was 0.25 and 1.22 , respectively. And, under the condition of poor nutrition, $v_{\mathrm{c}, \max }$ and $K_{\mathrm{c}}$, was 0.0039 and 0.32 , respectively. 


\section{Conclusion and Future Prospects}

The low-cost, environmentally friendly bioremediation technology is considered as one of the best approaches for cleaning up the petroleum polluted area. Some studies have testified that petroleum-contaminated shoreline could be restored by biodegradation technology within $2-5$ years. In the paper, the paper introduced that the species of oil-degrading microorganisms, degradation pathways and mechanisms, the degradation rate and reaction model, and the factors affecting the degradation.

With the increase of marine oil pollution accidents, it is necessary to solve some key issues about biodegradation in marine environment.

\section{After Bioremediation, the Risk Should be Assessed and Solved}

Risk of producing secondary contamination from the metabolites of hydrocarbon to the local environment should be identified. And the impact of cultivating petroleum degrading microorganisms to the local ecological system should be assessed.

\section{The Development of Mixed Local Microorganisms}

The studies indicated that the degradation rate is low for the remediation of complex mixture of contaminants by one species of petroleum degrading microorganisms. However, this rate could be improved using mixed local microorganisms, as each microorganism could degrade specific hydrocarbon compound by special active enzymes in themselves.

Acknowledgments This study was financially supported by the National Natural Science Foundation of China (Grant Nos. 51408347 and 21307149), the Key Laboratory of Marine Spill Oil Identification and Damage Assessment Technology, SOA (Grant No. 201407), Scientific Research Foundation of Shandong University of Science and Technology for Recruited Talents (Grant No. 2014RCJJ018), and the excellent young and middle-aged scientists of Shandong Province (Grant No. BS2013NJ019). Liping Wang was supported by NHMRC Grant (1094606).

\section{References}

1. Aeckersberg F, Bak F, Widdel F (1991) Anaerobic oxidation of saturated hydrocarbons to $\mathrm{CO}_{2}$ by a new type of sulfate-reducing bacterium. Arch Microbiol 156:5-14

2. Al-Mailem DM, Sorkhoh NA, Marafie M et al (2010) Oil phytoremediation potential of hypersaline coasts of the Arabian Gulf using rhizosphere technology. Bioresour Technol 101:5786-5792

3. Anderson CM, LaBelle RP (2000) Update of comparative occurrence rates for offshore oil spills. Spill Sci Technol Bull $6: 303-321$
4. Atlas RM (1975) Effects of temperature and crude oil composition on petroleum biodegradation. J Appl Microbiol 30:396-403

5. Atlas RM (1985) Effects of hydrocarbons on microorganisms and biodegradation in Arctic ecosystems. Elsevier, London

6. Atlas RM (1995) Petroleum biodegradation and oil spill bioremediation. Mar Pollut Bull 31:178-182

7. Atlas R, Bragg J (2009) Bioremediation of marine oil spills: when and when not-The Exxon Valdez experience. Microb Biotechnol 2:213-221

8. Bachmann RT, Johnson AC, Edyvean RG (2014) Biotechnology in the petroleum industry: an overview. Int Biodeterior Biodegradation 86:225-237

9. Bartha R, Atlas RM (1977) The microbiology of aquatic oil spills. Adv Appl Microbiol 22:225-266

10. Bao MT, Wang LN, Sun PY et al (2012) Biodegradation of crude oil using an efficient microbial consortium in a simulated marine environment. Mar Pollut Bull 64:1177-1185

11. Brakstad OG, Daling PS, Liv-G Faksness et al (2014) Depletion and biodegradation of hydrocarbons in dispersions and emulsions of the Macondo 252 oil generated in an oil-on-seawater mesocosm flume basin. Mar Pollut Bull 84:125-134

12. Boguslawska-Wạs E, Dạbrowski W (2001) The seasonal variability of yeasts and yeast-like organisms in water and bottom sediment of the Szczecin Lagoon. Int J Hyg Environ Health 203:451-458

13. Blumer M, Ehrhardt M, Jones JH (1973) The environmental fate of stranded crude oil. Deep-Sea Research and Oceanographic Abstracts 20:239-259

14. Bagi A, Pampanin DM, Lanzén A et al (2014) Naphthalene biodegradation in temperate and arctic marine microcosms. Biodegradation 25:111-125

15. Chaîneau CH, Rougeux G, Yéprémian C et al (2005) Effects of nutrient concentration on the biodegradation of crude oil and associated microbial populations in the soil. Soil Biol Biochem 37:1490-1497

16. Chaillan F, Chaîneau CH, Point V et al (2006) Factors inhibiting bioremediation of soil contaminated with weathered oils and drill cuttings. Environ Pollut 144:255-265

17. Chelsea S, William TS, Terry CH et al (2013) Distribution of hydrocarbons released during the 2010 MC252 oil spill in deep offshore waters. Environ Pollut 173:224-230

18. Choi SC, Kwon KK, Sohn JH, Kim SJ (2002) Evaluation of fertilizer additions to stimulate oil biodegradation in sand seashore mesocosms. J Microbiol Biotechnol 12:431-436

19. Colwell RR, Walker JD, Cooney JJ (1977) Ecological aspects of microbial degradation of petroleum in the marine environment. Crit Rev Microbiol 5:423-445

20. Das N, Chandran P (2011) microbial degradation of petroleum hydrocarbon contaminants: an overview. Biotechnol Res Int 13:1-13

21. Díez S, Jover E, Bayona JM et al (2007) Prestige oil spill. III. Fate of a heavy oil in the marine environment. Environ Sci Technol 41:3075-3082

22. Dutta TK, Harayama S (2001) Biodegradation of n-alkylcycloalkanes and n-alkylbenzenes via new pathways in Alcanivorax sp. strain MBIC 4326. Appl Environ Microbiol 67:1970-1974

23. Dyksterhouse SE, Gray JP, Herwig RP et al (1995) Cycloclasticus pugetii gen. nov., sp. nov., an Aromatic hydrocarbon-degrading bacterium from marine sediments. Int J Syst Bacteriol 45:116-123

24. Fingas MF (1995) A literature review of the physics and predictive modelling of oil spill evaporation. J Hazard Mater 42:157-175

25. Gallego S, Vila J, Tauler M et al (2013) Community structure and $\mathrm{PAH}$ ring-hydroxylating dioxygenase genes of a marine pyrene- 
degrading microbial consortium. Biodegradation. doi:10.1007/ s10532-013-9680-z

26. Giebel HA, Kalhoefer D, Lemke A et al (2011) Distribution of Roseobacter RCA and SAR11 lineages in the North Sea and characteristics of an abundant RCA isolate. ISME J 5:8-19

27. Gilbert JA, Steele JA, Caporaso JG et al (2012) Field, Defining seasonal marine microbial community dynamics. ISME J 6:298-308

28. Golyshin PN, Chernikova TN, Abraham WR et al (2002) Oleiphilaceae fam. nov., to include Oleiphilus messinensis gen. nov., sp. nov., a novel marine bacterium that obligately utilizes hydrocarbons. Int J Syst Evol Microbiol 52:901-911

29. Harayama S, Kishira H, Kasai Y et al (1999) Petroleum biodegradation in marine environments. $\mathrm{J}$ Mol Microbiol Biotechnol 1:63-70

30. Head IM, Jones DM, Röling WF (2006) Marine microorganisms make a meal of oil, Nature reviews. Microbiology 4:173-182

31. Harayama S, Kasai Y, Hara A (2004) Microbial communities in oil-contaminated seawater. Curr Opin Biotechnol 15:205-214

32. Hedlund BP, Staley JT (2001) Vibrio cyclotrophicus sp. nov., a polycyclic aromatic hydrocarbon (PAH)-degrading marine bacterium. Int J Syst Evol Microbiol 51:61-66

33. Hara A, Baik SH, Syutsubo K et al (2004) Cloning and functional analysis of alkB genes in Alcanivorax borkumensis SK2. Environ Microbiol 6:191-197

34. Hara A, Syutsubo K, Harayama S (2003) Alcanivorax which prevails in oil-contaminated seawater exhibits broad substrate specificity for alkane degradation. Environ Microbiol 5:746-753

35. Harris BC, Bonner JS, McDonald TJ et al (2002) Bioavailability of chemically-dispersed crude oil. In: Proceedings of the twentyfifth Arctic and Marine Oilspill Program (AMOP) Technical Seminar, Calgary, AB, Canada, pp 895-905

36. Iwabuchi N, Sunairi M, Urai M et al (2002) Extracellular polysaccharides of Rhodococcus rhodochrous S-2 stimulate the degradation of aromatic components in crude oil by indigenous marine bacteria. Appl Environ Microbiol 68:2337-2343

37. Jenkins ME, Adams MA (2011) Respiratory quotients and Q10 of soil respiration in sub-alpine Australia reflect influences of vegetation types. Soil Biol Biochem 43:1266-1274

38. Jiang WJ, Chen L, Batchu SR et al (2014) Oxidation of microcystin-LR by ferrate(VI): kinetics, degradation pathways, and toxicity assessments. Environ Sci Technol 48(20):12164-12172

39. Jiang WJ, Pelaez M, Dionysios D et al (2013) Chromium(VI) removal by maghemite nanoparticles. Chem Eng J 222(15):527-533

40. Jones DM, Head IM, Gray ND et al (2008) Crude-oil biodegradation via methanogenesis in subsurface petroleum reservoirs. Nature 451:176-180

41. Kanaly RA, Harayama S (2010) Advances in the field of highmolecular-weight polycyclic aromatic hydrocarbon biodegradation by bacteriambt-130 136.164. Microb Biotechnol 3:136-164

42. Kasai Y, Kishira H, Harayama S (2002) Bacteria belonging to the genus Cycloclasticus play a primary role in the degradation of aromatic hydrocarbons released in a marine environment. Appl Environ Microbiol 68:5625-5633

43. Kasai Y, Shindo K, Harayama S et al (2003) Molecular characterization and substrate preference of a polycyclic aromatic hydrocarbon dioxygenase from cycloclasticus sp. strain A5. Appl Environ Microbiol 69:6688-6697

44. Kim SJ, Choi DH, Sim DS et al (2005) Evaluation of bioremediation effectiveness on crude oil-contaminated sand. Chemosphere 59:845-852

45. Kiran GS, Hema TA, Gandhimathi R et al (2009) Optimization and production of a biosurfactant from the sponge-associated marine fungus Aspergillus ustus MSF3. Colloids Surf B 73:250-256

46. Ko JY, Day JW (2005) A review of ecological impacts of oil and gas development on coastal ecosystems in the Mississippi Delta. Ocean Coast Manag 47:597-623
47. Liu SY, Zhao YP, Jiang WJ et al (2014) Inactivation of Microcystis aeruginosa by electron beam irradiation. Water Air Soil Pollut 225:2093

48. Liu YC, Li LZ, Wu Y et al (2010) Isolation of an alkane-degrading Alcanivorax sp. strain 2B5 and cloning of the alkB gene. Bioresour Technol 101:310-316

49. Mills MA, Bonner JS, Page CA et al (2004) Evaluation of bioremediation strategies of a controlled oil release in a wetland. Mar Pollut Bull 49:425-435

50. Mnif S, Sayadi S, Chamkha M (2014) Biodegradative potential and characterization of a novel aromatic-degrading bacterium isolated from a geothermal oil field under saline and thermophilic conditions. Int Biodeterior Biodegradation 86:258-264

51. Oropesa AL, Pérez-López M, Hernández D et al (2007) Acetylcholinesterase activity in seabirds affected by the Prestige oil spill on the Galician coast (NW Spain). Sci Total Environ 372:532-538

52. Oudot J, Merlin FX, Pinvidic P (1998) Weathering rates of oil components in a bioremediation experiment in estuarine sediments. Mar Environ Res 45:113-125

53. Page CA, Bonner JS, Sumner PL et al (2000) Behavior of a chemically-dispersed oil and a whole oil on a near-shore environment. Water Res 34:2507-2516

54. Pasumarthi R, Chandrasekaran S, Mutnuri S (2013) Biodegradation of crude oil by Pseudomonas aeruginosa and Escherichia fergusonii isolated from the Goan coast. Mar Pollut Bull 76:276-282

55. Peng GW, Yang GX, Liu XC et al (2008) Isolation of a bacteria strain degrading crude oil and its degradation characteristics Chemical industry and engineering progress 27(531-534):557

56. Poland JS, Riddle MJ, Zeeb BA (2003) Contaminants in the Arctic and the Antarctic: a comparison of sources, impacts, and remediation options. Polar Record 39:369-383

57. Price PB, Sowers T (2004) Temperature dependence of metabolic rates for microbial growth, maintenance, and survival. Proc Natl Acad Sci USA 101:4631-4636

58. Pritchard PH (1991) EPA 's Alaska oil spill bioremediation project. Environ Sci Technol 25:372-379

59. Prince RC, McFarlin KM, Butler JD et al (2013) The primary biodegradation of dispersed crude oil in the sea. Chemosphere 90:521-526

60. Meckenstock Rainer U (2004) Anaerobic degradation of polycyclic aromatic hydrocarbons. FEMS Microbiol Ecol 49(1):27-36

61. Robador A, Brüchert V, Jørgensen BB (2009) The impact of temperature change on the activity and community composition of sulfate-reducing bacteria in arctic versus temperate marine sediments. Environ Microbiol 11:1692-1703

62. Rontani JF, Bosser-Joulak F, Rambeloarisoa E (1985) Analytical study of Asthart crude oil asphaltenes biodegradation. Chemosphere 14:1413-1422

63. Saito A, Iwabuchi T, Harayama S (1999) Characterization of genes for enzymes involved in the phenanthrene degradation in Nocardioides sp. KP7. Chemosphere 38(6):1331-1337

64. Shi J, Chen Z, Hu X et al (2000) The effects of petroleumdegrading bacteria on the n-alkanes. Donghai Mar Sci 18:21-27

65. Singer ME, Finnerty WR (1984) Microbial Metabolism of Straight-Chain and Branched Alkanes. Macmillan Publishing Co., New York

66. Singh H (2006) Mycoremediation: Fungal Bioremediation. John Wiley \& Sons, New Jersey

67. Soddell JA, Stainsby FM, Eales KL et al (2006) Gordonia def luvii sp. nov., an actinomycete isolated from activated sludge foam. Int J Syst Evol Microbiol 56:2265-2269

68. Staley JT (2010) Cycloclasticus: a genus of marine polycyclic aromatic hydrocarbon degrading bacteria. In: Timmis KN (ed) Handbook of Hydrocarbon and Lipid Microbiology. Springer, Berlin, Heidelberg, pp 1782-1785 
69. Swannell RPJ, Mitchell D, Lethbridge G et al (1999) A field demonstration of the efficacy of bioremediation to treat oiled shorelines following the Sea Empress incident. Environ Technol 20:863-873

70. Torres MA, Barros MP, Campos SCG et al (2008) Biochemical biomarkers in algae and marine pollution: a review. Ecotoxicol Environ Saf 71:1-15

71. Venosa AD, Suidan MT, Wrenn BA et al (1996) Bioremediation of an experimental oil spill on the shoreline of Delaware Bay. Environ Sci Technol 30:1764-1775

72. Vila J, López Z, Sabaté J et al (2001) Identification of a novel metabolite in the degradation of pyrene by Mycobacterium sp. strain AP1: actions of the isolate on two- and three-ring polycyclic aromatic hydrocarbons. Appl Environ Microbiol 67: 5497-5505

73. Wang Y, Lau PCK, Button DK (1996) A marine oligobacterium harboring genes known to be part of aromatic hydrocarbon degradation pathways of soil pseudomonads. Appl Environ Microbiol 62:2169-2173

74. Yakimov MM, Giuliano L, Gentile G et al (2003) Golyshin, Oleispira antarctica gen. nov., sp. nov., a novel hydrocarbonoclastic marine bacterium isolated from Antarctic coastal sea water. Int J Syst Evol Microbiol 53:779-785
75. Yakimov MM, Golyshin PN, Lang S et al (1998) Alcanivorax borkumensis gen. nov., sp. nov., a new, hydrocarbon-degrading and surfactant-producing marine bacterium. Int J Syst Bacteriol 48:339-348

76. Yassine MH, Suidan MT, Venosa AD (2013) Microbial kinetic model for the degradation of poorly soluble organic materials. Water Res 47:1585-1595

77. Yuan HL, Yang JS, Wang ZS et al (2003) Microorganism screening for petroleum degradation and degrading characteristics. China Environmental Science 23:157

78. Yumoto I, Nakamura A, Iwata $\mathrm{H}$ et al (2002) A novel, facultatively psychrophilic alkaliphile that grows on hydrocarbons. Int J Syst Evol Microbiol 52:85-90

79. Zhang JL, Li ZY, Wang L et al (2003) Biological degradation of crude oil in seawater. J Univ Sci Technol Beijing 25:410-413

80. Zhang ZE, Yan YF, Zhang L et al (2014) Hollow fiber membrane contactor absorption of $\mathrm{CO}_{2}$ from the flue gas: review and perspective. Global NEST Journal 16(2):355-374

81. Zhang Z, Yan Y, Zhang L et al (2014) Theoretical study on $\mathrm{CO}_{2}$ absorption from biogas by membrane contactors: effect of operating parameters. Ind Eng Chem Res 53(36):14075-14083 